\title{
各種貴金属触媒を用いたピレンおよびフルオランテンの 選択的水素化反応
}

\author{
（1986 年 2 月: 1 日 受理）
}

持田 勲* 大平正人・坂西欣也・藤津 博

市肘の 5 種の活性炭担持貴金属 ( $\mathrm{Pd}, \mathrm{Pt}, \mathrm{Rh}, \mathrm{Ru}, \mathrm{Rh}-\mathrm{Ru}$ ，担持率 $5 \mathrm{wt} \%$ ) 触媒を用いるピレンお よびフルオランテンの選択的部分水素化を試みた。標準反応条件 $\left(250^{\circ} \mathrm{C}, \mathrm{H}_{2}\right.$ 反応圧 $50 \mathrm{~kg} / \mathrm{cm}^{2}, 6$ 時 間）で触媒スクリーニングを行なったところ，ジヒドロピレン〔2]，テトラヒドロピレン［5]につい ては $\mathrm{Pd} / \mathrm{C}$ ，へキサヒドロピレン〔3],[4]については， Rh/C がもっとも高い収率を与えた。これら の触媒を用いて最適条件を探索したところ, ジヒドロ体については, 最大収率 $48 \%\left(\mathrm{Pd} / \mathrm{C}, 200^{\circ} \mathrm{C}, \mathrm{H}_{2}\right.$ 反応圧 $70 \mathrm{~kg} / \mathrm{cm}^{2}, 1$ 時間), テトラヒドロ体 [5] については, $84 \%\left(\mathrm{Pd} / \mathrm{C}, 150^{\circ} \mathrm{C}, \mathrm{H}_{2}\right.$ 反応圧 70 $\mathrm{kg} / \mathrm{cm}^{2}, 16$ 時間) が得られた。

一方, フルオランテンについては，いずれの触媒を用いても，テトラヒドロフルオランテンが高収率 （80\%）で得られた。

水素化生成物变化から，ピレンの水素化経路を提案した。さらに，貴金属の種類と生成物選択性との 関連について議論した。

\section{1 緒 言}

ピレン, フルオランテンなどの芳香族多環炭化水素の部分水素 化体は，石炭の一次液化反応や炭素繊維プレカーサーピッチの調 製に打いて,高溶解能·高水素供与能を兼社えた備れた溶剂とし て威力を発揮することが知られている121。一方，これら芳香族多 環炭化水素のファインケミカル的な利用においても, 重要な出発 原料となる。このため, 部分水素化体の選択的合成法が望まれて いる。石炭液化溶媒などの調製にしばしば使用される $\mathrm{Ni}-\mathrm{Mo} / \mathrm{\gamma}$ $\mathrm{Al}_{2} \mathrm{O}_{3}$ 触媒によって, ピレンなどの部分水素化反応を試みると, かなりの高圧が必要で，特定の部分水素化体の選択率もたかたか $40 \%$ 程度である3)。Li-エチレンジアミンを用いる Benkeser 還 元によるピレンの部分水素化反応子報告されているが4)，ジヒド 口体が主生成物であり，テトラヒドロ体の選択性は低い.5)。ジヒ ド口体は熱的に不安定で, 酸化により容易に重合する 。貴金属 触媒を用いた水装化 ${ }^{78)}$ や，アルカリ金属を用いた水素化の， Ni-

九州大学生産科学研究所, 816 春日市春日公園

1) I. Mochida, Y. Moriguchi, Y.Korai, H. Fujitsu, K. Takeshita, Fuel, 60, 746(1981).

2) I. Mochida, K. Takeshita, "Coal Liquefaction Fundamentals” ACS Symposium Series, 139, 259(1981).

3) I. Mochida, K. Otani, Y. Korai, H. Fujitsu, Chem. Lett., 1983, 1025.

4) R. A. Benkeser, R. E. Robinson, D. M. Sauve, O. H. Thomas, J. Am. Chem. Soc., 77, 3230(1951).

5) I. Mochida, K. Tamaru, Y. Korai, H. Fujitsu, K. Takeshita, Carbon, 19, 213(1981).

6) I. Mochida, K. Tamaru, Y. Korai, H. Hatano, ibid., 23, 237(1985).

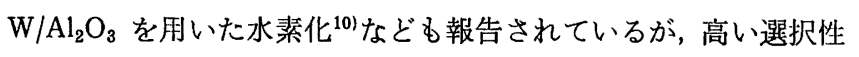
は得られていない。

一方, フルオランテンは, 市肘の $\mathrm{NiMo} / \gamma-\mathrm{Al}_{2} \mathrm{O}_{3}$ 触媒でも, か なり高選択率で $1,2,3,10 \mathrm{~b}$-テトラヒドロフルオランテンを与え るが，この場合もかなりの高压を必要とする。

著者らは, 石炭液化プロセスにおいて, 水素化工程がもっとも 高压を必要とすることに着目し，この工程の水素圧を低減するこ とにより，低圧液化プロセスを開発することを意図している。そ こで本報では，低温低圧下でも高い水素化能を有する各種の貴金 属触媒 ( $\mathrm{Pd}, \mathrm{Pt}, \mathrm{Rh}, \mathrm{Ru}, \mathrm{Rh}-\mathrm{Ru})$ を用いて, 温和な条件でピ レンおよびフルオランテンを部分水素化し，優れた液化溶媒とな る部分水素化体を選択的に調製することを試みた。この結果, 触媒 および水素化の最適条件の探索の過程で, 反応温度 ・ 反応時間に 対する水素化生成物の変化を追跡した。これらの結果に基づき, ピレン,フルオランテンの水素化反応経路を議論した。

\section{2 実娩}

ピレン,フルオランテンおよび溶媒（デカリン）は, 市販の特 級試薬 (和光純薬 (株) 製) を使用した。触媒は, 市肘のカーボ ン担持各種貴金属 ( $\mathrm{Pd}, \mathrm{Pt}, \mathrm{Rh}, \mathrm{Ru}, \mathrm{Rh}-\mathrm{Ru}$ ) 触媒（日本エン

7) P.P.Fu, H. M. Lee, R. G. Harvey, J. Org. Chem., 45, 2797(1980).

8) P. P. Fu, R. G. Harvey, Tetrahedron Lett., 1977, 415.

9) S. Friedman, M. L. Kaufman, I. Wedner, J. Org. Chem., 36, 694(1971).

10) J. Shabtai, L. Veluswamy, A. G. Oblad, Prep. PapAm. Chem. Soc. Div. Fuel. Chem., 23(1), 107 (1978). 
Table 1 Catalytic activity of noble metals on carbon for hydrogenation of pyrene $\mathrm{e}^{a)}$

\begin{tabular}{|c|c|c|c|c|c|c|c|}
\hline \multirow{2}{*}{ Catalyst } & \multirow{2}{*}{$\begin{array}{c}\text { Conditions } \\
{ }^{\circ} \mathrm{C} / \mathrm{kg} \cdot \mathrm{cm}^{-2} / \mathrm{h}\end{array}$} & \multirow{2}{*}{$\begin{array}{c}\text { Conv. } \\
(\%)\end{array}$} & \multicolumn{5}{|c|}{ Yield/Selectivity (\%) } \\
\hline & & & {$[2]$} & {$[3]$} & [4] & [5] & Others \\
\hline $\mathrm{Pt} / \mathrm{C}$ & $250 / 50 / 6$ & 82 & $\frac{38}{46}$ & $\frac{6.4}{7.7}$ & $\frac{3.6}{4.3}$ & $\frac{32}{39}$ & $\frac{1.8}{2.2}$ \\
\hline $\mathrm{Pd} / \mathrm{C}$ & " & 87 & $\frac{40}{47}$ & $\frac{5.5}{6.4}$ & $\frac{3.9}{4.6}$ & $\frac{35}{41}$ & $\frac{2.0}{2.2}$ \\
\hline $\mathrm{Rh} / \mathrm{C}$ & $" \prime$ & 83 & $\frac{31}{37}$ & $\frac{23}{27}$ & $\frac{4.6}{5.6}$ & $\frac{20}{25}$ & $\frac{4.7}{5.5}$ \\
\hline $\mathrm{Rh}-\mathrm{Ru} / \mathrm{C}$ & "I & 85 & $\frac{26}{30}$ & $\frac{28}{33}$ & $\frac{6.9}{8.1}$ & $\frac{16}{19}$ & $\frac{8.5}{10}$ \\
\hline $\mathrm{Ru} / \mathrm{C}$ & " & 71 & $\frac{43}{60}$ & $\frac{2.7}{3.8}$ & $\frac{1.6}{2.2}$ & $\frac{21}{30}$ & $\frac{2.6}{3.7}$ \\
\hline
\end{tabular}

a) Pyrene $2 \mathrm{~g}$, Cat. $0.5 \mathrm{~g}$, Decalin $10 \mathrm{~g}$.

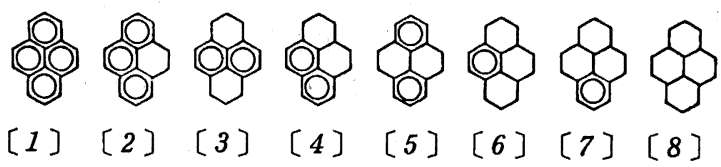

ゲルハルド (株) 製，担持率 $5 \mathrm{wt} \%$ ) を用いた。

ピレンあるいはフルオランテン $2.0 \mathrm{~g}$ に, デカリン（溶媒） 10 $\mathrm{g}$ ，各種貴金属触媒を，ピレシに対しては $0.5 \mathrm{~g}$, フルオランテン に対しては $0.2 \mathrm{~g}$ を電磁かきまぜ式オートクレーブ (内容積 : 50 $\mathrm{ml}$ ) に装入し，オートクレーブ内を窒素で置換し，ついで所定压 の水素を充填した。ピレンの水素化に対する触媒のスクリーニン グでは, 反応温度 $250^{\circ} \mathrm{C}$, 反応圧力 $50 \mathrm{~kg} / \mathrm{cm}^{2}$, 反応時間 6 時間 を標準条件とした。ジヒドロ，テトラヒドロ，およびへキサヒド 口体の選択合成においては, 反応温度, 反応圧力, 反応時間, 括 よび昇温速度の転化率ならびに選択率におよぼす影響を調べ，そ れぞれについて最適反応条件を探索した。

所定時間反応後, 放冷し, オートクレーブ内部を THF で洗浄 して反応生成物を回収した。触媒を沪別したのち, 必要に応じて THF あるいはデカリンを減圧留去し，生成物は， GC (FID 検 出器, カラム : $\mathrm{SE}-30,2 \mathrm{~m}$, カラム温度 : $100 \rightarrow 270^{\circ} \mathrm{C}$ ), 昇温速 度 : $10^{\circ} \mathrm{C} / \mathrm{min}$ ) により分析した。生成物の同定は, 既報の方法 ${ }^{11}$ および市肘品 $(1,2,3,6,7,8$-ヘキサヒドロピレン) あるいは別途 合成水素化体との比較, ならびに GC-MS, 分取後の ${ }^{1} \mathrm{H}-\mathrm{NMR}$ スペクトルによった。得られた生成物の構造および略号は，表 1 扣よび 2 に示した。

\section{3 結 果}

3.1 ピレンの選択水素化反応に対する触媒のスクリーニング

表 1 にピレンの選択水素化反応に対する各種金属触媒のスクリ ーニングの結果をまとめた。反応温度 $250^{\circ} \mathrm{C}$, 反応王力 $50 \mathrm{~kg} /$ $\mathrm{cm}^{2}$ 反応時間 6 時間の条件下では, これらの触媒の活性は, Ru/C がやや低い（転化率 71\%）以外はほ注同じである。選択性は，Pt/ $\mathrm{C}$ および $\mathrm{Pd} / \mathrm{C}$ が〔2]，〔5]の選択率が高く（[2]+[5]： $85 \%$ 以上)， $\mathrm{Rh} / \mathrm{C}$ 扎よび $\mathrm{Rh}-\mathrm{Ru} / \mathrm{C}$ は, 〔2〕，〔5〕の選択率が 低いかわりに〔3〕の選択率が比較的高い(約 30\%)。

3.2 ジヒドロ体 [2] およびテトラヒドロ体 [5]の選択合成 〔2]または〔5]の選択合成にもっとも有効と考えられる $\mathrm{Pd} /$ C (表 1 参照) を用いて，各種反応条件下〔2〕の選択合成を試

11) Y. Nakatsuji, T.Kubo, M. Nomura, S. Kikkawa, Bull. Chem. Soc. Jpn., 51, 618(1978).

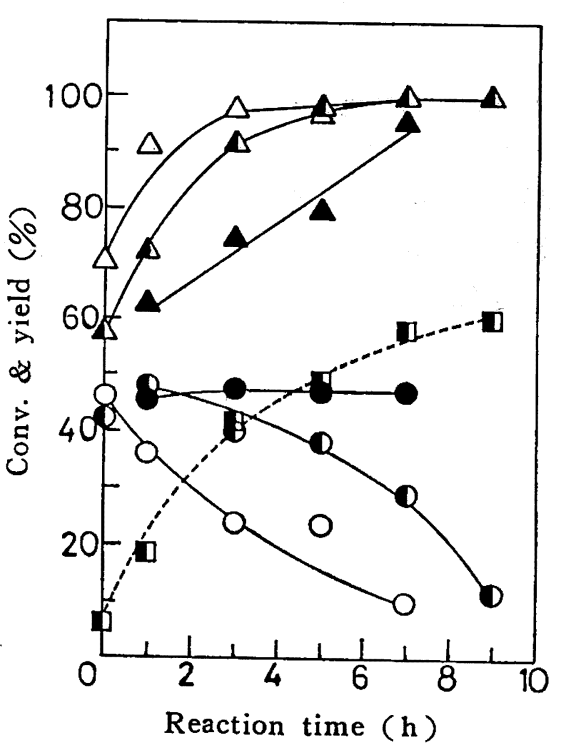

Fig. 1 Selective hydrogenation of pyrene to dihydropyrene [2]

$\mathrm{H}_{2}$ Press. $70 \mathrm{~kg} / \mathrm{cm}^{2}$, Cat. $\mathrm{Pd} / \mathrm{C}$

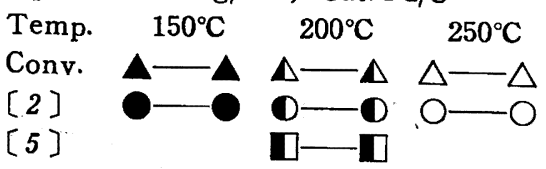

みた結果を図 1 に示した。反応水素圧 $70 \mathrm{~kg} / \mathrm{cm}^{2}$ で, 反応温度を $150,200,250^{\circ} \mathrm{C}$ と変えて水素化反応を行なったところ, 各温度 で転化率およびそれにともなう選択率の経時変化の様相は異なる ものの, いずれの場合も〔2]の最大収率は $50 \%$ 弱であった。 反応温度 150 および $200^{\circ} \mathrm{C}$ での最大選択率は，それぞれ $73 \%$ (転化率 $63 \%$ )，66\%（転化率 72\%）であった。その後，反応時 間の経過掞よび転化率の増加とともに，〔2〕の選択率は次第に 娍少しそそれに代わって $200^{\circ} \mathrm{C}$ (図 1 ：【卵) で代表して示した ように〔5〕がいちじるしく增大した。つまり〔2]は反応時間 の経過とともに，逐次的に〔5]へと水素化が進んでいる。

$\mathrm{Pd} / \mathrm{C}$ 触媒を用いて，[5]の選択合成を試みた結果を図 2 に示 した。反応温度 $150^{\circ} \mathrm{C}$, 反応水素圧 $70 \mathrm{~kg} / \mathrm{cm}^{2}$ の条件で，転化率 


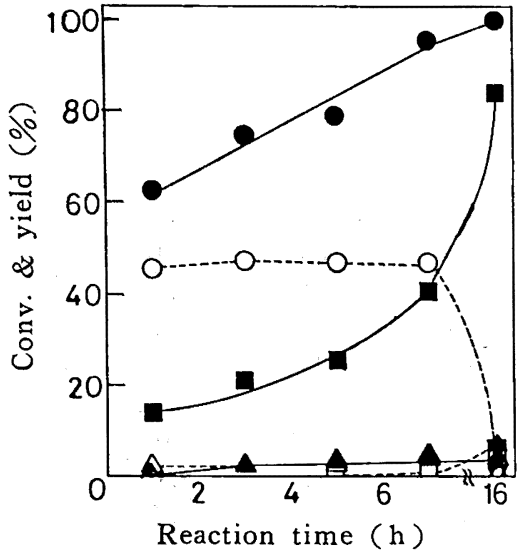

Fig. 2 Selective hydrogenation of pyrene to tetrahydropyrene [5]

$\mathrm{H}_{2}$ Press. $70 \mathrm{~kg} / \mathrm{cm}^{2}$, Temp. $150^{\circ} \mathrm{C}$, Cat. $\mathrm{Pd} / \mathrm{C}$

Conv.

[2]

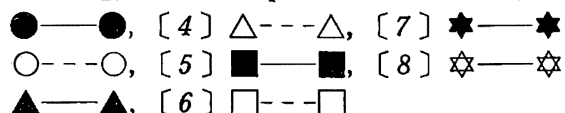

[3]

$\Delta-\Delta,[6]$

および生成物収率の経時変化を追跡したところ，〔2〕および 〔5〕がほぼ選択的に生成し，ほかの生成物はほとんど生成しな かった。反応時間を16 時間に延長すれば，〔2〕を逐次選択的に 〔5〕に水素化でき，〔5〕の最大収率 83\%（選択率 84\%) を達 成することができた。

\section{3 ヘキサヒドロ体 [3]の選択合成}

〔3〕の選択合成を試みるために, 触媒のスクリーニングで [3]の選択率が高かった $\mathrm{Rh} / \mathrm{C}$ を用いて, 反応温度 $300^{\circ} \mathrm{C}$, 反応 水素圧 $70 \mathrm{~kg} / \mathrm{cm}^{2}$ の条件でピレンの水素化を行なった。図 3 にそ の転化率および生成物収率の経時変化を示した。昇温速度 $8^{\circ} \mathrm{C} /$ $\min$ で反応温度 $300^{\circ} \mathrm{C}$ に加熱した場合（図 3a)),〔3〕が反応 時間 2 時間で最大収率 $50 \%$ で合成できた。このさい，反応時間
ゼロ（つまり昇温終了時点）で，すでに〔2〕扣よび〔5】が合わ せて $55 \%$ も生成していることから，昇温過程に拈ける（つまり 低温での)〔2〕拈よび〔5]の生成が，〔3]の選択率向上の妨 げになっていると予想できる。そこで高速昇温 $\left(20^{\circ} \mathrm{C} / \mathrm{min}\right)$ によ る水素化を行なってみたところ（図 $3 \mathrm{~b}$ ))，〔2〕拈よび〔5〕の 昇温時の生成は抑制でき，〔3〕の収率は転化率とともに增大し， 反応洔間 2 時間で最大収率 $52 \%$ （選択率 56\%) に増えた。この 時点で, すでにデカヒドロ体〔6]が $17 \%$ ，へキサヒドロ体［4] が 15\% 生成しており，これらが〔3〕の選択率の向上を阻害し ていると推定される。さらに反応時間を延長すると，〔3]の選 択率は減少し，〔6]がいちじるしく增加した。

ところで図 3 a) に拈いて, 〔5]の減少とともに〔3](あるい は〔4]）が增大寸る傾向があり，〔5]から〔3]（あるいは[4]） への水素化をともなった異性化反応経路の存在が示唆される。実 際に〔5]（テトラヒドロピレン）を $76 \%$ 含む水素化ピレンを調 製し, 反応温度 $300^{\circ} \mathrm{C}$ ，反応水素圧 $70 \mathrm{~kg} / \mathrm{cm}^{2}$ で， $\mathrm{Rh} / \mathrm{C}$ 触媒を 用いて反応させた結果を図 4 に示した。反応開始後 1 分で [5] は急激に減少し，かわって〔3]あるいは〔4〕のへキサヒドロ 体が増加した。さらに反応時間を延長すると，3分で〔3〕の収 率は最大 $45 \%$ に達し，5分では減少し始めた。一方，〔4]の減 少は 1 分後に始まり，それとともに〔6]のデカヒドロ体が増加 した。

\section{4 フルオランテンの水素化}

$\mathrm{Pd} / \mathrm{C}$ 触媒を用いたフルオランテンの水素化反応結果を表 2 に まとめた。反応温度 $150^{\circ} \mathrm{C}$, 反応水素圧 $30 \mathrm{~kg} / \mathrm{cm}^{2}$, 反応時間 0.5 時間の稳和な条件で，すでに転化率は $100 \%$ に達し，生成物む $75 \%$ がデカヒドロ体であった。さらに穏和な反応温度 $100,75^{\circ} \mathrm{C}$, 反応時間 0.5 時間の条件では，それぞれ転化率は $100,63 \%$ で, テトラヒドロ体〔2']の選択率は，それぞれ 77, $88 \%$ であっ た。このように, フルオランテンはピレンにくらべて非常に水素 化反応性が高く，テトラヒドロ体の選択合成も比較的容易にでき
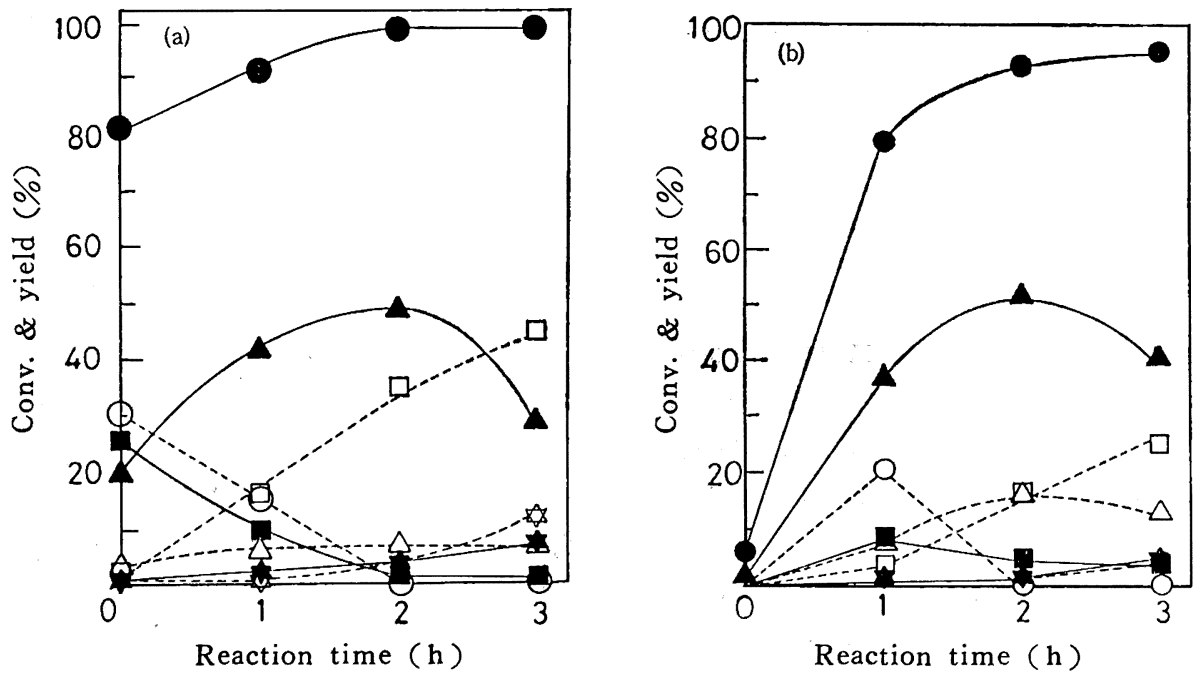

Fig. 3 Selective hydrogenation of pyrene to hexahydropyrene [3]

a) Low heating rate $8^{\circ} \mathrm{C} / \mathrm{min}$, b) High heating rate $20^{\circ} \mathrm{C} / \mathrm{min}$ $\mathrm{H}_{2}$ Press. $70 \mathrm{~kg} / \mathrm{cm}^{2}$, Temp. $300^{\circ} \mathrm{C}$, Cat. $\mathrm{Rh} / \mathrm{C}$ Conv. 


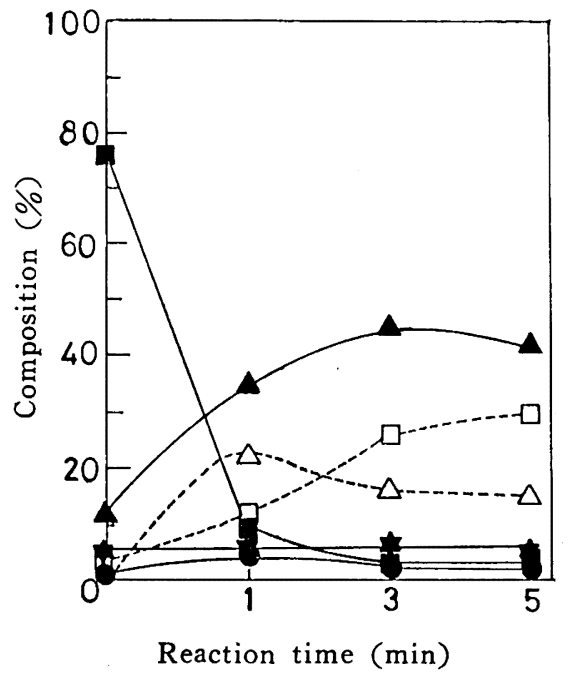

Fig. 4 Hydroisomerization of tetrahydropyrene [5]

$\mathrm{H}_{2}$ Press. $70 \mathrm{~kg} / \mathrm{cm}^{2}$, Temp. $300^{\circ} \mathrm{C}$, Cat. $\mathrm{Rh} / \mathrm{C}$

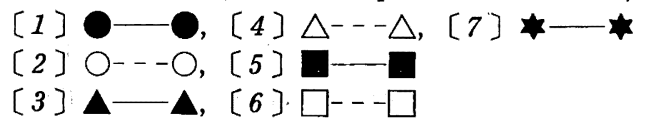

$[3] \mathbf{\Delta}-\mathbf{\Delta},[6] \cdot \square---\square$

Table 2 Catalytic hydrogenation of fluoranthene over $\mathrm{Pd} / \mathrm{C}^{a}$

\begin{tabular}{|c|c|c|c|c|c|}
\hline \multirow{2}{*}{$\begin{array}{l}\text { Conditions } \\
{ }^{\circ} \mathrm{C} / \mathrm{kg} \cdot \mathrm{cm}^{-2} / \mathrm{h}\end{array}$} & \multirow{2}{*}{$\begin{array}{l}\text { Conv. } \\
(\%)\end{array}$} & \multicolumn{4}{|c|}{ Yield/Selectivity (\%) } \\
\hline & & {$\left[2^{\prime}\right]$} & {$\left[3^{\prime}\right]$} & $\begin{array}{l}{\left[4^{\prime}\right]} \\
+\left[5^{\prime}\right]\end{array}$ & {$\left[6^{\prime}\right]$} \\
\hline \multirow{2}{*}{$150 / 30 / 0.5$} & \multirow{2}{*}{100} & 18 & 2.2 & 75 & 4.8 \\
\hline & & 18 & $\overline{2.2}$ & 75 & $\overline{4.8}$ \\
\hline \multirow{2}{*}{$100 / 20 / 0.5$} & \multirow{2}{*}{100} & 77 & 13 & 9.7 & 0.3 \\
\hline & & 77 & 13 & $\overline{9.7}$ & $\overline{0.3}$ \\
\hline \multirow{2}{*}{$75 / 30 / 0.5$} & \multirow{2}{*}{63} & 56 & 6.1 & 1.3 & 0.0 \\
\hline & & 88 & $\overline{9.6}$ & $\overline{2.0}$ & $\overline{0.0}$ \\
\hline
\end{tabular}

a) Fluoranthene $2 \mathrm{~g}$, Catalyst $0.2 \mathrm{~g}$, Decalin $10 \mathrm{~g}$.

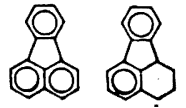

$\left[1^{\prime}\right]$

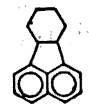

$\left[3^{\prime}\right]$

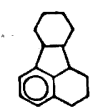

$\left[4^{\prime}\right]$

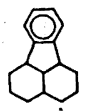

$\left[5^{\prime}\right]$

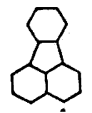

$\left[6^{\prime}\right]$
た。

\section{4 考察}

各種贵金属触煤を用いたピレンの水素化反応結果から, 図 5 に 示したよらなピレンの水素化経路が考光られる。太い実線で示し たのが低温に拈ける捄もな反応経路で，〔1]から〔2]，〔2]か ら[5], さらに[7], [8]へと逐次的に反応が進む。したがっ て $\mathrm{Pd} / \mathrm{C}$ を用いる低温の水素化では, 反応を〔5]の段階で止め ることができ，[5]を高選択率, 高収率で合成することができ た。しかし，〔2〕から〔5〕への反応は速く，〔2〕を高收率で 合成することはできなかった。これは，孤立した〔5]のベンゼ ン環の水素化反応性がかなり低いのに対して，〔2〕のフェナン トレン骨格の中心の環の反応性が高いことを反映しているのであ ろう。

一方, $\mathrm{Rh} / \mathrm{C}$ 触媒を用いる高温の水素化反応では, 〔1〕から [3]への経路が可能となり得る。同時に，〔5]の[3]あるい

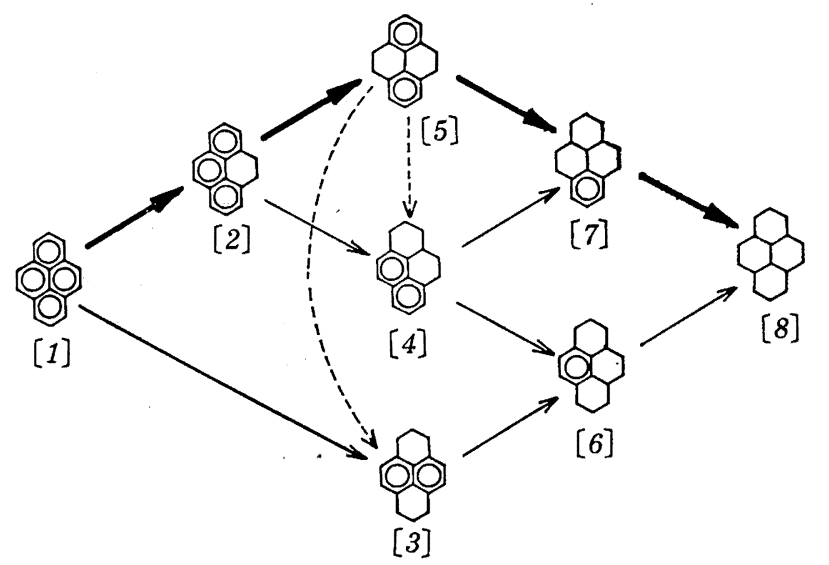

Fig. 5 Hydrogenation pathway of pyrene

は〔4]への水素化をともなった異性化が進行した。こうして高 速昇温 $\left(20^{\circ} \mathrm{C} / \mathrm{min}\right), 300^{\circ} \mathrm{C}, 2$ 時間の反応で，〔3〕を $52 \%$ の収 率で合成できた。しかし，〔4]あるいは〔6]もかなり副生し， これ以上の収率向上はできなかった。〔3]をさらに高選択的に 合成するためには，高温高圧下の短時間反応により [1] $\rightarrow[3]$ の経路の寄与を拻大するか, あるいは [5] $\rightarrow[3]$ への水素化を ともなった異性化反応を選択的に進行させるような反応条件を探 索する必要がある。

ジヒドロおよびテトラヒドロピレンの選択合成には $\mathrm{Pd} / \mathrm{C}$, 人 キサヒドロピレンの選択性向上には $\mathrm{Rh} / \mathrm{C}$ が適していだ。 Pd の 場合に 4,5-位から優先的に水素化され，つづいて9,10-位が水素 化される理由としては，Harvey らが報告しているよらに7)，Pd は局在化した $\pi$ あるいは $\sigma$ 錯体の形成により，最小の結合非局在 化エネルギーの領域である K-reagion（つまり，4,5-位 および 9,10-位) に, 協奏的に水素添加する機構が優先することが举げ られる。表 3 にピレンの反応性指数を揭げた ${ }^{12)}$ 。Pd 触媒上では 協奏的水素化のため, 反応性のもっとも高い1-位圆は, 隣接位置 の反応性が低いため優先せず，4,5-位置が水素化される。このこ とは， $\mathrm{C}_{4}-\mathrm{C}_{5}$ 結合がもっとも結合距離が短い(つまりもっとも結 合次数が大きい)ことからも理解できる ${ }^{13)}$ 。しかし，水素活性化 能（エチレンに対する水素化能）の高いRh 触媒を高温で使用す れば，1-位置の水素化が有利となり，〔3〕の収率が向上すること が理解できる。発生期の水素を使用する還元的水素化では, 1 の 位㯰の水素化が優先することが知られている ${ }^{14)}$ 。なお，[5]から [3]への水素化をともなった異性化は, 高温で熱力学的に安定 な〔3]への平衡化反応として進行するのであるう。

図6にフルオランテンの水素化反応経路を示した。〔1'〕から

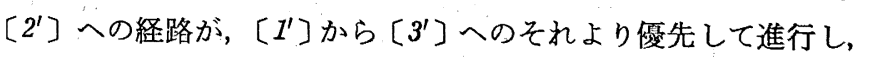
その後の $\left[4^{\prime}\right],\left[5^{\prime}\right]$ への水素化反応も, 比較的㩊和な条件ですみ やかに進む。表 3 によれば，1-拈よび3-位置の自由原子価が大き く ${ }^{15)}$, この位置がまず優先的に水素化される。協奏反応を考えて も, 同様に 2,3-位置の水素化が優先しょう。2-位に水素原子が導

\footnotetext{
12）米沢貞次郎, 永田親義, 加藤博史, 今村 詮, 諸熊奎治, “改訂量子化学入門(上)”, 化学同人 (1968) p. 211.

13) V. Buss, H. D. Försterling, Tetrahedron, 29, 3001 (1973).

14) A. Disp, Beil, 5( 1), 315(1942).

15）日本化学会糄，“化学便覧基礎楄 II”, 丸善（1966）p.861.
} 
Table 3 Reactivity indexes of pyrene and fluoranthene

\begin{tabular}{ccccccc} 
Position & $\begin{array}{c}\text { Localiza- } \\
\text { tion } \\
\text { energy } \\
\text { (Lr) }\end{array}$ & $\begin{array}{c}\text { Frontier } \\
\text { electron } \\
\text { density } \\
\text { (fr) }\end{array}$ & $\begin{array}{c}\text { Super- } \\
\text { delocaliz- } \\
\text { ability } \\
\text { (Sr) }\end{array}$ & $\begin{array}{c}\text { Self- } \\
\text { polariz- } \\
\text { ability } \\
(\pi \mathrm{rr})\end{array}$ & $\begin{array}{c}\text { Free } \\
\text { valence } \\
\text { (Fr) }\end{array}$ \\
\hline & 1 & 2.189 & 0.272 & 1.116 & 0.467 & 0.469 \\
& 2 & 2.549 & 0.000 & 0.829 & 0.395 & 0.394 \\
& 4 & 2.275 & 0.175 & 1.025 & 0.444 & 0.452 \\
& 1 & 1.61 & 0.167 & 1.049 & & 0.453 \\
& 2 & 1.82 & 0.069 & 0.861 & & 0.398 \\
& 3 & 1.54 & 0.284 & 1.137 & & 0.470 \\
& 7 & 1.71 & 0.136 & 0.937 & & 0.438 \\
& 1.76 & 0.086 & 0.909 & & 0.409
\end{tabular}

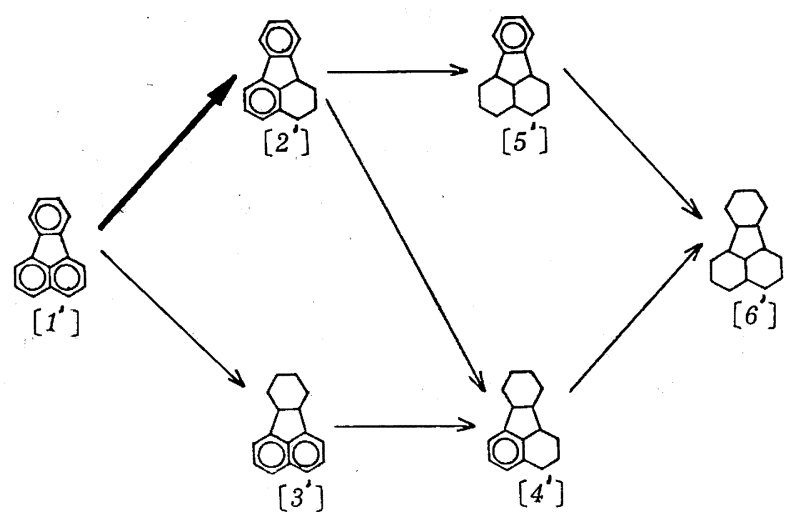

Fig. 6 Hydrogenation pathway of fluoranthene

入されれば，残った孤立二重結合の水素化は速い。このため [2']

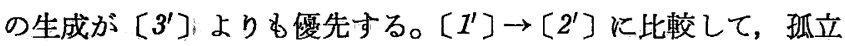
ベンゼン環を水素化することになる $\left.2^{\prime}\right] \rightarrow\left[4^{\prime}\right]$ あるいは [5 $]$
の反応は遅く，したがっていずれの触媒でも〔2']の選択的合成 は比較的容易である。フルオランテンのナフタレン環部分とベン ゼン環部分とを結ぶ五員環の結合次数は小さく，また芳香族性の 尺度となる反磁性磁化率は $\Lambda=42$ で, ベンゼン $(\Lambda=13.7)$ と ナフタレン $(\Lambda=30.5)$ の和に注注等しいことから, 両芳香環間 の共役は恃とんどないと考兄られる ${ }^{16)}$ 。上で述べた [2']の優先 性は，ベンゼンとナフタレンの反応性の違い㶤起因すると考苀ら れる。

ところで, フルオランテンはピレンに比較してかなり温和な条 件で, 水素化が大きな速度で進行する。基質間の反応性が議論で きるスーパーディロカリザビリティー（Sr) や自由原子洒 ( Frr) をもっとも反応性の高い隣接位置の和で比較すると, 両者で大き な差はないか，むしろピレンの方がわずかながら大きい。詳細は 不明であるが, 局在化エネルギーの大きな差を反映しているのか も知れない。

16）村田一郎, 山本景祚, 日本化学会編, “化学総説 No. 15, 新しい芳香族系の化学”, 学会出版センター (1977) p. 228.

\section{Selective Hydrogenation of Pyrene and Fluoranthene Using Various Noble Metal Catalysts}

Isao Mochida*, Masato Ohira, Kinya Sakanishi and Hiroshi Fujitsu

Research Institute of Industrial Science, Kyushu University; Kasugakoen, Kasuga-shi 816 Japan

Selective hydrogenation of pyrene and fluoranthene to the corresponding partially hydrogenated derivatives was studied using noble metals on carbon under $30 \sim 70$ atm of hydrogen. $\mathrm{Pd} / \mathrm{C}$ catalyst was most selective to produce dihydro- [2] and tetrahydropyrene [5] with the best yields of $48 \%$ and $84 \%$ at $200^{\circ} \mathrm{C}$ and $150^{\circ} \mathrm{C}$ for $1 \mathrm{~h}$ and $16 \mathrm{~h}$, respectively. The decreasing yield of [2] with the prolonged reaction time was due to its successive hydrogenation. Higher reaction temperature of $300^{\circ} \mathrm{C}$ and use of $\mathrm{Rh} / \mathrm{C}$ catalyst were favorable for the production of hexahydropyrene [3]. Because of the favorable production of [2] and [5] at lower temperatures, rapid heating to the reaction temperature was suggested to be effective to obtain an increased yield of [3]. Hydrogenation of fluoranthene was more rapid and selective : the reaction using $\mathrm{Pd} / \mathrm{C}$ catalyst at $100^{\circ} \mathrm{C}$ for $0.5 \mathrm{~h}$ at 20 atm provided tetrahydrofluoranthene in $77 \%$ selectivity at $100 \%$ conversion. Based on the product analyses in the course of the reactions, competitive and successive nature of pyrene hydrogenation were suggested. Hydrogenative isomerization of [5] to [3] was ascertained to occur in the reaction with [5]. 